\title{
The relative importance of trophy harvest and retaliatory killing of large carnivores: South African leopards as a case study
}

\author{
Lourens H. Swanepoel ${ }^{1}$, Peter Lindsey ${ }^{3}$, Michael J. Somers ${ }^{1,4}$, \\ Wouter Van Hoven ${ }^{1}$ \& Fredrik Dalerum ${ }^{1,2 *}$ \\ ${ }^{1}$ Centre for Wildlife Management, Hatfield Experimental Farm, University of Pretoria, Private Bag X20, Hatfield, 0028 South Africa \\ ${ }^{2}$ Mammal Research Institute, Department of Zoology and Entomology, University of Pretoria, \\ Private Bag X20, Hatfield, 0028 South Africa \\ ${ }^{3}$ Endangered Wildlife Trust, Private Bag X11, Modderfontein, 1645 South Africa \\ ${ }^{4}$ Centre for Invasive Biology, University of Pretoria, Private Bag X20, Hatfield, 0028 South Africa \\ Received 6 June 2013. Accepted 20 December 2013
}

\begin{abstract}
There are considerable challenges in the conservation of large carnivores, caused by large area requirements, low reproduction rates and low population densities coupled with their tendency to cause conflict with humans. Trophy hunting is one strategy to increase support for large carnivore conservation. Leopards, Panthera pardus, rank among the most soughtafter trophies in South Africa. However, trophy hunting has been suggested as partly responsible for leopard population declines, and leopards are also killed in retaliatory actions. In this study we used a stochastic population model to evaluate the relative influences of retaliatory killing and trophy harvest on leopard population persistence, and to assess the sustainability of the current leopard trophy harvest in South Africa. There was a stronger effect of variation in retaliatory killing than of harvest on population persistence. Although we found low extinction risks for South African leopards within 25 years, high risks of population declines across a wide range of simulation scenarios call for concern regarding the viability of the South African leopard population. We suggest that conflict mitigation may be more effective in promoting leopard persistence than restricting trophy harvest, and that accurate estimates of retaliatory killing are necessary for assessments of harvest sustainability.
\end{abstract}

Key words: trophy hunting, carnivore, adaptive management, simulation models, population viability analysis.

\section{INTRODUCTION}

Conservation biologists and wildlife managers face considerable challenges in the management and conservation of large carnivores (Noss et al. 1996). Large carnivores have extensive area requirements, low reproduction rates and normally occur at low densities (Purvis et al. 2000). Furthermore, protected areas are rarely large enough to maintain viable large carnivore populations (Linnell et al. 2001). Therefore, non-protected areas are important in the conservation of large carnivores (Funston et al. 2013). However, carnivore populations in non-protected areas are frequently in conflict with rural communities, commercial farmers and game keepers, and retaliatory killing in response to human-large carnivore conflict is common (Woodroffe \& Ginsberg 1998; Dar et al.

*To whom correspondence should be addressed.

E-mail: fredrik.dalerum@zoology.up.ac.za
2009; Dickman 2010). Such conflict-related killing can have both direct and indirect demographic consequences for carnivore populations (Treves \& Karanth 2003). For example, legal and illegal retaliatory killing of large carnivores can result in the removal of mature, reproductively active individuals (Woodroffe \& Frank 2005; Baker et al. 2008). Retaliatory killing can thus hamper carnivore population sustainability as well as impede the recovery of threatened populations (Woodroffe \& Frank 2005; Kaczensky et al. 2011).

Commercial exploitation, like trophy hunting, is often used as an incentive in non-protected areas to increase local tolerance towards large carnivore populations (Lewis \& Jackson 2005; Treves 2009). Appropriately managed trophy hunting can contribute significantly to local economies, and financial returns from hunting may in some cases exceed the cost of predation (Lindsey et al. 2012; Funston 
et al. 2013). Trophy hunting may therefore be a powerful financial tool to increase persistence and population viability of some large carnivores in non-protected areas (Funston et al. 2013). However, the effectiveness of trophy hunting as a viable conservation tool relies on harvest at demographically sustainable levels (Packer et al. 2009). While trophy hunting may not generally pose a major threat to wildlife populations (Lindsey et al. 2007), it has been suggested that poorly managed trophy hunting quotas can be a contributing factor for causing declines in populations of some large carnivores (e.g. Packer et al. 2009; Packer et al. 2011). Furthermore, the sustainability of trophy hunting can be adversely affected by retaliatory killing (Loveridge et al. 2009). It is therefore important to evaluate the importance of retaliatory killing and trophy hunting simultaneuously when evaluating the sustainablity of harvest levels.

Leopards (Panthera pardus) are widely distributed throughout South Africa (Friedmann \& Daly 2004) and they are frequently killed in conflict with livestock or game farmers (Inskip \& Zimmerman 2009; Thorn et al. 2012). Trophy hunting is often seen as an appropiate incentive to conserve leopards (Lindsey et al. 2007; Funtson et al. 2013), but concern over the sustainability of leopard trophy hunting in South Africa has been raised (Balme et al. 2009). These concerns are founded in a doubling of the harvest quota since 2005 (75 to 150 animals), as well as increased incidents of legal and illegal retaliatory killing (Daly et al.2005). Coupled with recent concerns that poorly managed trophy hunting may be partly responsible for declining leopard populations (Balme et al. 2009; Packer et al. 2011), there thus appears to be a need for a formal evaluation of the sustainability of the current trophy harvest of South African leopards.

Population viability analyses (PVA) are commonly used to evaluate the effects and importance of management actions, like trophy hunting, on population persistence (Reed et al. 2002). The interpretability of a PVA is, however, dependent on the quality of underlying population parameters (Dalerum et al. 2008). Since such demographic data typically are limited for large carnivores, including leopards (Daly et al. 2005), it is often difficult to interpret results from PVAs for these species. A potentially effective PVA method for such situations is to combine stochastic population models with logistic regression (McCarthy et al. 1995; McCarthy et al. 1996). This approach provides a qualitative assessment of the influence of demographic parameters on extinction risk, and can be used to estimate risk over a wide range of potential demographic and intervention scenarios. It also has the additional advantage that it allows for assessments of interactions among parameters (Cross \& Beissinger 2001; Dalerum et al. 2008).

In this study we combined binary output from a stochastic population model with logistic regression to evaluate the effects of different scenarios of harvest and retaliatory killing on leopard population persistence, with the dual aim of (i) qualitatively assessing the relative importance of trophy hunting and retaliatory killing for a large carnivore species, and (ii) assessing if the current CITES quota is a cause of concern for the South African leopard population under realistic ranges of population sizes and retaliatory killing.

\section{MATERIALS AND METHODS}

\section{Model structure}

Rather than trying to provide numerical values for recommended harvest levels, we used a qualitative simulation approach where we focused on evaluating the effects of different combinations of retaliatory killing and harvest scenarios on population persistence (Starfield 1997; Pe'Er et al. 2013). This approach allowed us to evaluate uncertainty in retaliatory killing over a range of potential levels of trophy harvest.

We used a previously described stochastic population model with a simple sex and age structure (Dalerum et al. 2008). The model can be defined as:

$$
P_{t}=A M_{t}+A F_{t}+S M_{t}+S F_{t}+J_{t}
$$

where $P_{t}$ is population size, $A M_{t}$ and $A F_{t}$ is the number of adult males and females, $S M_{t}$ and $S F_{t}$ is the number of subadult males and females, and $J_{t}$ is the number of juveniles at year $t$, respectively. The model is temporally discrete with time steps of one year. Following Swanepoel et al. (in press), we regarded animals older than three years to be adults, animals between one and three years to be subadults and animals less than one year old to be juveniles. Although we capped population size at four times its initial value, we did not include any density dependent effects on demographic parameters as this theoretical carrying capacity was approached. We chose to use a density independent approach partly because data on density dependent demographic regulation are lacking 
for leopards and similar large felids, and partly because we assumed that South African populations are largely limited by a combination of suitable habitat and persecution, and therefore are unlikely to occur at densities that approach carrying capacity defined by resource limitation (see Caro et al. 2009).

\section{Model parameters}

We used published demographic information for leopards to parameterize the model. A summary of all model parameters and their sources are given in Appendix 1. We estimated initial population structure to be $30 \%$ adult males, $30 \%$ adult females, $15 \%$ subadult males and females respectively, and $10 \%$ juveniles. Each time step we drew fecundity from Poisson distributions with a mean annual litter size per female of 1.41 and calculated the total number of juveniles in a given year by summarizing the fecundity of all females. We drew baseline annual survival probabilities from binomial distributions with averages reflecting age and sex specific survival estimated as $91 \%, 85 \%, 82 \%$, $93 \%$ and $33 \%$ for adult males and females, subadult males and females, and juveniles, respectively (Appendix 1). These values were taken from a recent meta-analysis of leopard survival in southern Africa (Swanepoel et al., in press). Although infanticide has been reported as a major cause of juvenile mortality in one leopard population (Balme et al.2013), there are no data available to quantify the effects of male turnover on such infanticide rates (e.g. Swenson et al. 1997). Furthermore, infanticidal mortality is included in our juvenile survival estimates (Swanepoel et al., in press). We therefore believe that explicit inclusion of the demographic effects of infanticide in our models will only introduce unquantifiable uncertainty, which will hamper the interpretability of the simulation output. We estimated the number of emigrants out of each province from binomial emigration probabilities set to $47 \%$ for subadult males, $14 \%$ for subadult females and $5 \%$ for adults. We calculated the number of immigrants into a province as the sum of the number of emigrants from each neighbouring province scaled by the proportional length of the land border between each pairs of provinces. For international borders, we calculated an average number of immigrants per km of border within South Africa for the respective province, and multiplied this number by the length of the international border. We assumed equal survival for animals migrating between provinces as for animals remaining within their natal province.

We multiplied leopard densities derived from literature and unpublished sources by spatially explicit probabilities of occurrences derived from a habitat suitability model to calculate realistic ranges of provincial population sizes (Swanepoel et al. 2013). Source studies used to estimate these densities are given in Appendix 2. Each study was assigned to a major biome, and to incorporate uncertainty in density estimates we calculated a minimum, median and maximum density for each biome. We multiplied these densities by the pixel specific probability of occurrence from our habitat suitability model to calculate the number of leopards per pixel, and estimated provincial leopard population sizes by summarizing the number of animals for all pixels in each province (Table 1). Estimated minimum, median and maximum densities for each province and biome are given in Appendix 3.

We collected information on leopard harvest and retaliatory killing from provincial nature conservation offices for the period 2000-2010. These data contained the number of trophy hunted animals, legally killed problem animals (Damage Causing Animals, DCA) and illegally killed animals. Based on these data, we estimated the sex ratio of hunted leopards under CITES trophy permits to be $68 \%$ males and the age structure to be $95 \%$ adults, and the sex and age structure for retaliatory killing (i.e. estimated from animals killed under DCA permits) to be $65 \%$ males and $72 \%$ adults (Appendix 1 ). Due to low compliance to legislation regarding damage-causing leopards, only a low number of reports are received for DCA permits issued, as well as leopards killed under such permits (ChaseGrey 2011). For example, in the Limpopo province reports were only received for $28 \%$ of DCA permits issued. Furthermore, record-keeping capabilities varied among provinces, with only Limpopo and KwaZulu-Natal having adequate records on DCA permits issued. Because of these two issues, the number of reported animals killed under DCA permits in each province was low. Therefore, to estimate how many leopards were killed under DCA permits we also collected the number of DCA permits issued for Limpopo and KwaZuluNatal from 2005 to 2010 (provinces with adequate DCA data). Harvest and retaliatory killing statistics for the South African provinces are listed in Appendix 4.

We set limits for likely ranges of trophy harvest from zero harvest to four times the maximum 
Table 1. The range of leopard population sizes and maximum levels of trophy harvest and retaliatory killing used for the simulations for each South African province.

\begin{tabular}{|c|c|c|c|c|}
\hline \multirow[t]{2}{*}{ Province } & \multicolumn{2}{|c|}{ Population size ${ }^{a}$} & \multirow{2}{*}{$\begin{array}{c}\text { Trophy harvest } \\
\text { Maximum }^{b}\end{array}$} & \multirow{2}{*}{$\begin{array}{l}\text { Retaliatory mortality } \\
\text { Maximum }^{c}\end{array}$} \\
\hline & Minimum & Maximum & & \\
\hline Limpopo & 1682 & 7168 & 204 & 348 \\
\hline Mpumalanga & 338 & 1851 & 32 & 169 \\
\hline North West & 174 & 255 & 40 & 54 \\
\hline Gauteng & 25 & 31 & 4 & 8 \\
\hline Northern Cape & 68 & 262 & 14 & 27 \\
\hline Free State & 8 & 26 & 4 & 8 \\
\hline KwaZulu-Natal & 247 & 1120 & 20 & 118 \\
\hline Western Cape & 200 & 619 & 32 & 65 \\
\hline Eastern Cape & 71 & 299 & 16 & 33 \\
\hline South Africa & 2813 & 11632 & 366 & 826 \\
\hline
\end{tabular}

${ }^{a}$ Minimum and maximum population sizes were calculated by multiplying the lowest and highest recorded density in each major biome by spatially derived explicit probabilities of leopard occurrence derived from a habitat suitability model (Appendix 2, Appendix 3).

${ }^{b}$ Represents four times the maximum recorded trophy harvest per year over the period 2002-2010 (Appendix 4), or for provinces without existing harvest the average proportional harvest based on the provinces with existing harvest. Minimum levels were set to zero for each province.

${ }^{c}$ Represents the maximum number of damage-causing leopards killed or translocated per year over the period 2002-2010 (Appendix 4) and an estimated number of illegally killed leopards. Minimum levels were set to zero for each province.

recorded harvest per year in each province. To set an upper limit to harvest for provinces where no harvest had occurred, we first calculated the maximum recorded proportional harvest based on the median population size from the provinces where harvest had occurred. This value was then multiplied by the median population size of the respective province that had been without harvest. We similarly set the lower limits for likely ranges of retaliatory killing at zero killed animals per year in each province. We set the upper limit of likely ranges of retaliatory killing to the maximum number of issued DCA permits plus an estimated number of illegally killed animals. For provinces where we did not have number of issued permits, we calculated maximum proportional annual number of permits per leopard based on the median population sizes in Limpopo and KwaZulu-Natal (where we did have information on number of issued permits), and multiplied this number by the median population sizes for provinces where we did not have information of number of issued permits.

Estimating the number of illegally killed animals was more challenging because detecting illegal killing of carnivores is difficult (Kaczensky et al. 2011). During 2010 an anonymous amnesty was given to farmers in the Eastern Cape if they gave information on the number of leopards killed illegally during the years 2004-2010 (Lindsey et al. 2011). We therefore used the amnesty data from Eastern Cape in an attempt to quantify illegal killing of leopards in other provinces. To do this we first calculated the proportion of leopards estimated from the median population size that was illegally killed in the Eastern Cape. This proportion was then multiplied by the median population size in the other provinces. Likely ranges of harvest and retaliatory killing for each province and for South Africa that were used in our simulations are given in (Table 1).

\section{Simulations and data analyses}

We generated 1000 parameter combinations by sequentially altering values of harvest, retaliatory killing and population sizes within ranges described above. We ran 100 simulations for each parameter combination, resulting in a total of 100000 individual simulations. For each simulation, we captured population size after 25 years and coded this population size as extinct if fewer than two animals remained or as having declined if it was below initial population size. We used these binary response codes as response variables in generalized linear models to calculate the probability of extinction and population declines (McCarthy et al. 1995; Cross \& Beissinger 2001; Dalerum et al. 2008). We used initial population size, trophy harvest, retaliatory killing as well as all interaction terms as predictors. The models were fitted with a binomial error structure and with a logit link function. We have not reported any evaluations of the test statistics from our logistic models since statistical inference is dependent on sample size, which in simulated data is arbitrarily determined (e.g. number 
of simulation runs; McCarthy et al. 1995; Dalerum et al. 2008). Instead, we have presented standardized odds ratios for each model term as a qualitative approach of evaluating their relative influence on extinction risk and risk of population decline (Kaufman 1996). All population simulations and statistical analyses were conducted using $R$ version 2.15.1 for Linux (http://www.r-project.org).

\section{RESULTS}

For most provinces, retaliatory killing had substantially higher odds ratios than trophy harvest, both for extinction risk and risk of population decline (Table 2). This highlights that within the evaluated ranges, variation in retaliatory killing had a more pronounced effect on extinction risk and risk of population decline than variation in trophy harvest. The odds ratios for all interaction terms were close to 1 for most provinces (Table 2), which suggests limited interactive effects between trophy harvest, retaliatory killing and population size. The low odds ratios for the effect of population size on extinction risk highlight the positive effect of population size on population persistence. However, for some provinces, as well as for South Africa as a whole, the odds ratios for the effect of population size on risk of population decline was above 1 , which suggests a positive association between population size and risk of decline in these areas.

At low to intermediate levels of retaliatory killing, neither the South African leopard population as a whole nor any of the provinces seem to be under serious extinction risk under the current level of trophy harvest (South Africa: 69 animals per year; Limpopo: 51 animals; Mpumalanga: 7 animals; North West: 7 animals; KwaZulu-Natal: 4 animals; Appendix 4), but extinction risk increased across all harvest levels with increasing rates of retaliatory killing in all but two provinces (Fig. 1). Moreover, both the South African leopard population as well as some provinces, most notably Limpopo, Mpumalanga, KwaZulu-Natal and the Western Cape, showed persistent risks of population decline across all evaluated scenarios (Fig. 2).

\section{DISCUSSION}

Our simulations pointed to substantially higher effects of variation in retaliatory killing than of variation in trophy harvest on population persistence. We acknowledge that these results could at least be party caused by the wider ranges of retaliatory killing that we simulated compared to harvest, for which the upper limits generally did not reach critical levels to cause increased risks of extinction or population decline. However, we estimated upper limits of retaliatory killing from empirical data, and we set upper limits of harvest to four times the current harvest levels, which must be regarded as liberate. We therefore argue that our results are empirically relevant, because they highlight that the number of animals killed in retaliatory actions can widely exceed the number of animals killed for recreational harvest. Our study thus conforms to previous concerns about the potential effects of persecution on large carnivore population persistence (Treves \& Karanth 2003). However, our results contradict some recent studies that have suggested negative demographic effects of trophy harvest alone (Caro et al. 2009; Packer et al. 2011), and support suggestions that retaliatory killing may enhance such negative effects (Loveridge et al. 2009).

The limited relative effect of trophy harvest on population persistence highlights its potential as a strategy to increase local tolerance for large carnivores by providing sustainable incomes (Lewis \& Jackson 2005; Treves 2009). However, hunters need to be actively involved in management plans, landowners need to receive associated benefits, and incomes need to exceed any financial losses associated with the presence of predators for positive effects to occur (Treves \& Martin 2011). In our simulations, the demographic impacts of retaliatory killing and trophy harvest were also completely additive. The demographic impacts of trophy harvest could therefore be further minimized if it is designed to be compensatory with respect to the killing of conflict animals, i.e. if it is directed towards areas with high potential for conflict, or targeting animals that have been identified to cause conflict (Stein et al. 2010).

Our results call for concern regarding the sustainability of the South African leopard population. Although our simulations suggested that the extinction risk of the South African leopard population was negligible within the next 25 years, we found an unequivocal risk of population decline in South Africa as a whole as well as for several provinces. Because of the dramatic effects of retaliatory killing on population persistence, our results highlight that reliable data on legal and illegal retaliatory killing are paramount for our ability to assess the sustainability of any given harvest level. Moreover, our results suggest that control of conflictrelated killing may be more effective than restricting the CITES quota for harvested animals. Such 


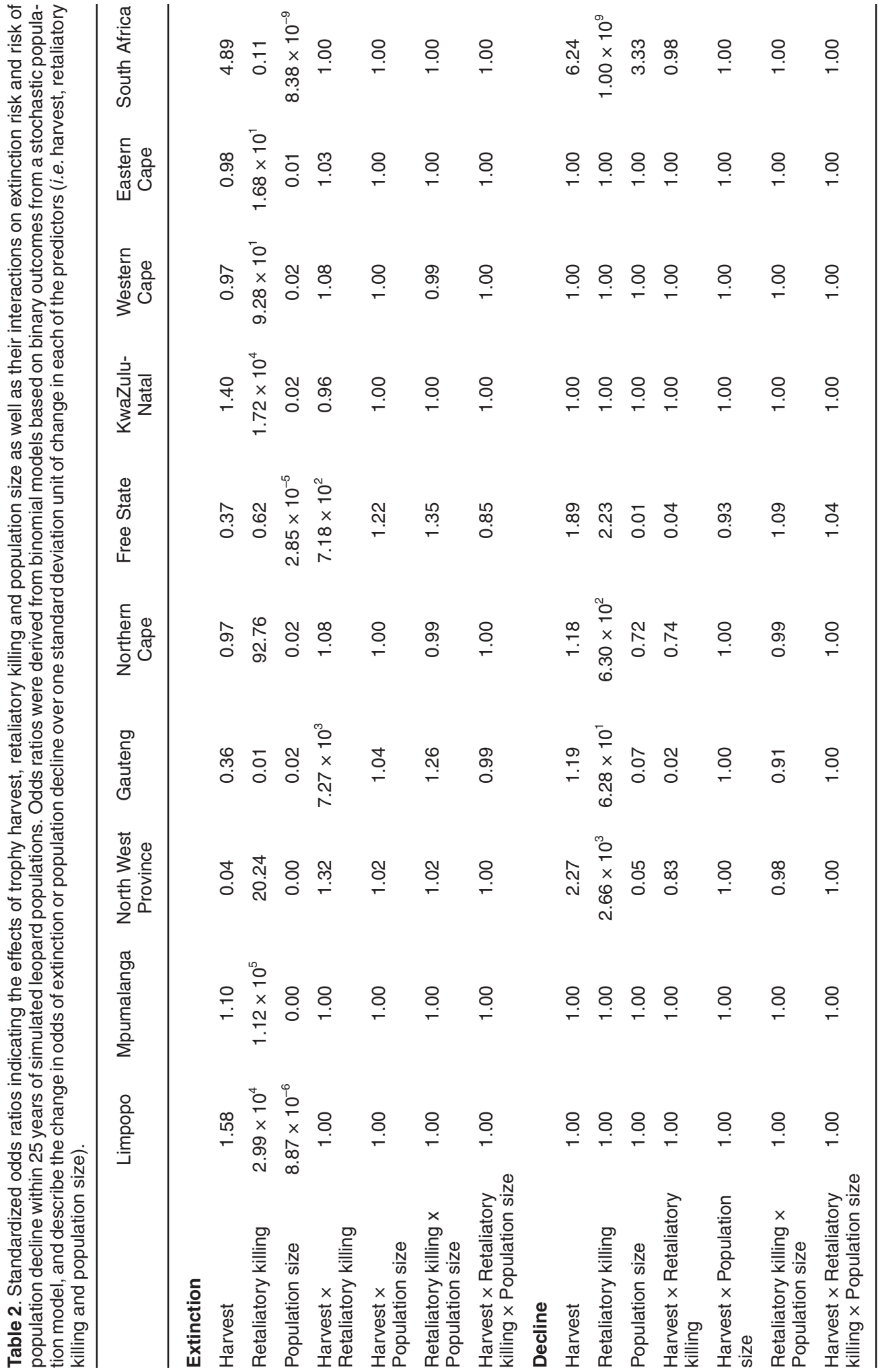



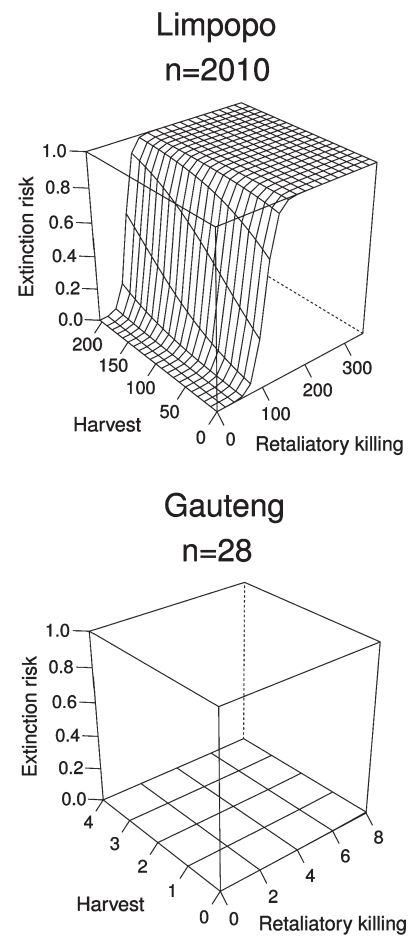

KwaZulu-Natal $\mathrm{n}=590$

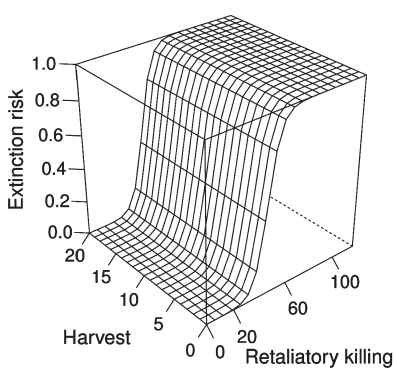

Mpumalanga

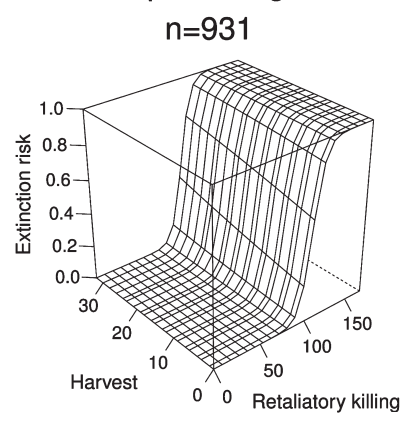

Northern Cape

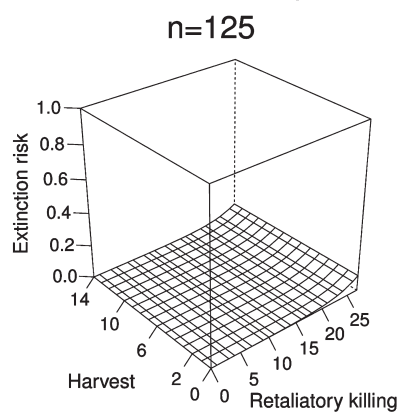

Western Cape

$\mathrm{n}=358$

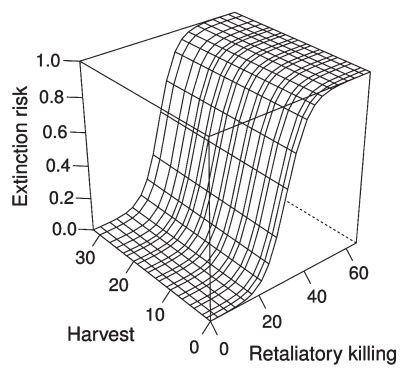

South Africa

$n=4476$

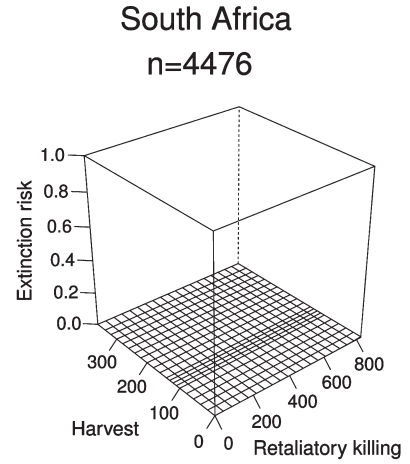

North West

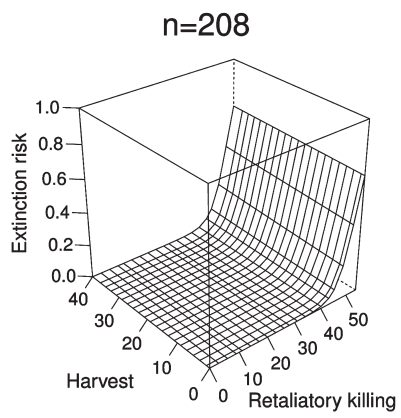

Free State

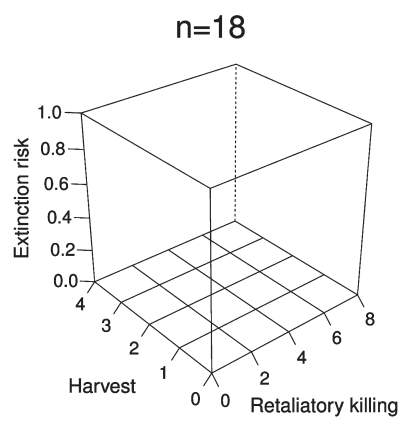

Eastern Cape

$n=181$

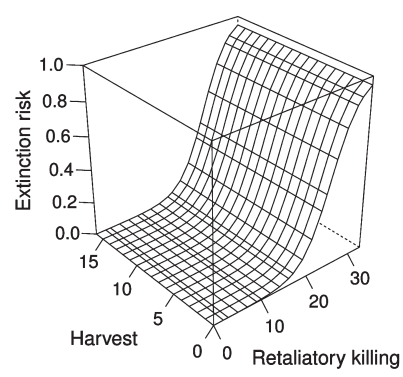

Fig. 1. Predicted extinction risk after 25 years of simulations of provincial leopard populations in South Africa under realistic ranges of trophy harvest and retaliatory killing. Extinction risks were calculated from logistic regression models based on binary outcomes from a stochastic population model. Extinction risks were calculated on the median estimated population estimates within each province, which are indicated in the figure. 

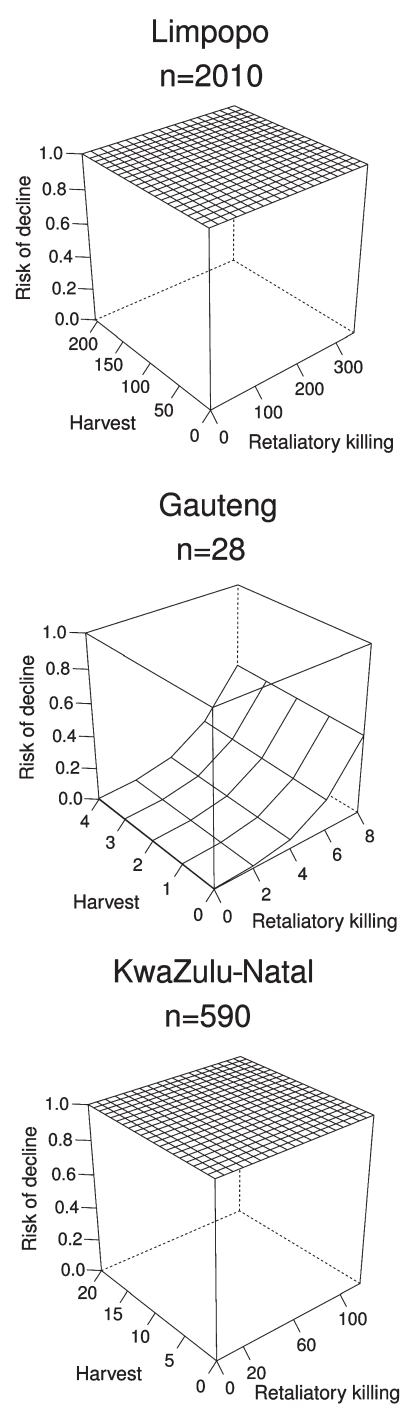
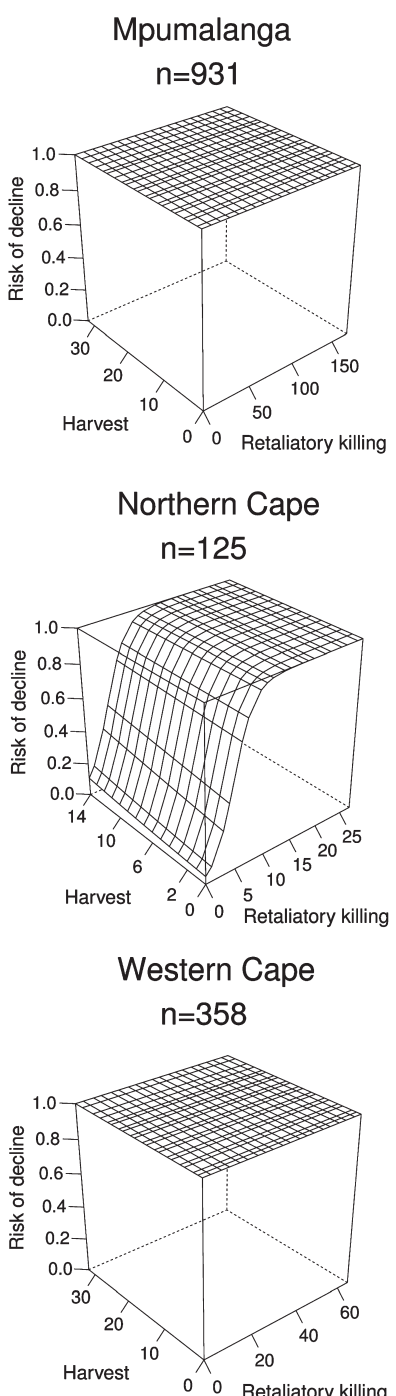

South Africa $n=4476$

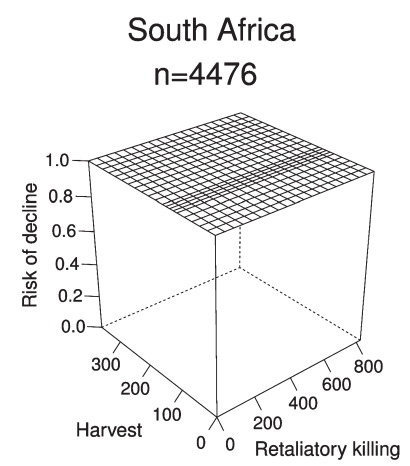

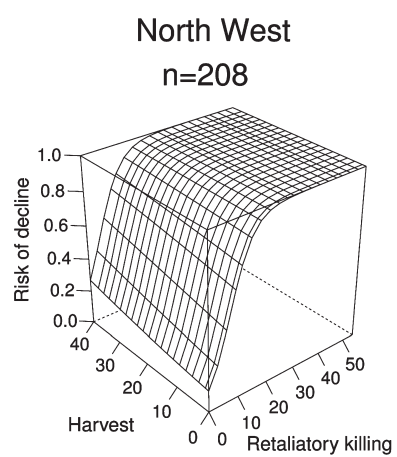
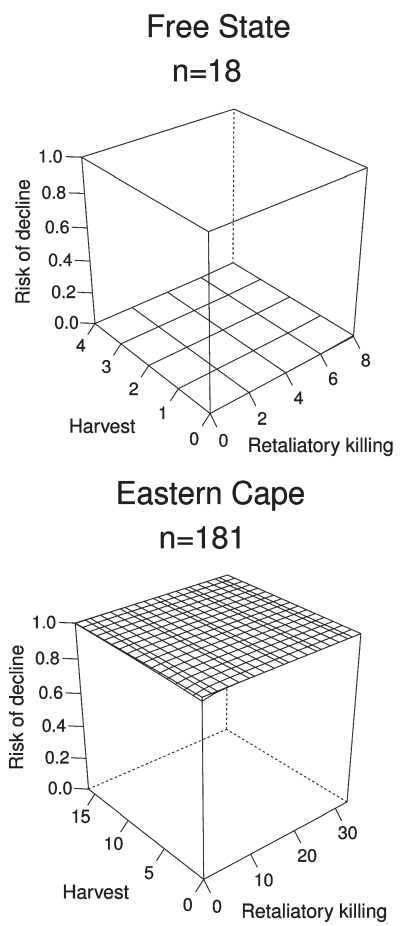

Fig. 2. Predicted risk of population decline after 25 years of simulations of provincial leopard populations in South Africa under realistic ranges of trophy harvest and retaliatory killing. Risks of decline were calculated from logistic regression models based on binary outcomes from a stochastic population model, where a decline was scored if the population size after 25 years of simulation was lower than the initial population size. Risks of decline were calculated based on the median estimated population estimates within each province, which are indicated in the figure. 
conflict mitigation could for instance include the use of livestock protection schemes such as livestock-guarding dogs (Ogada et al. 2003), but also educational components targeting wildlife associated value norms within local communities (Madden 2004). Adequate and functional compensatory programmes have also been shown effective (Swenson \& Andrén 2005), but are highly costly alternatives for financially developing countries.

Some provincial populations experienced high probabilities of decline without experiencing either harvest or retaliatory killing. Since these provinces all had large estimated population sizes, we suggest two, not necessarily mutually exclusive, explanations. First, we parameterized emigration as a proportion of population size, and calculated immigration as the sum of the emigrants from neighbouring provinces. Therefore, provinces with large populations that were surrounded by much smaller ones could experience a net deficit in animals caused by a net emigration that could be enough to cause high risks of population declines. Second, our median population size estimates could be above the demographically stable population sizes given our demographic parameters, so that the observed declines could be the results of a demographic stabilization process. However, our median estimated population size for South Africa (4476 leopards) falls well below the only previous formal attempt to estimate the South African population size (23 472 individuals; Martin \& de Meulenaar 1988), and generally agrees with estimates based on expert opinion (e.g. 2000-3000 animals: Norton 1990, and 4250 animals: Daly et al. 2005). We therefore suggest that factors other than overestimated population sizes caused the elevated probabilities of decline at zero harvest and retaliatory killing in these provinces. We note that three of these provinces, Limpopo, Mpumalanga and KwaZulu-Natal, currently have leopard harvest, which could call for caution in setting harvest quotas for these areas.

Finally, we identify some caveats with our simulation efforts. First, our simulations were based on limited demographic data, including only South African studies (Bailey 2005; Balme et al. 2010). We also indirectly estimated leopard population sizes from a habitat suitability model (VanDerWal et al. 2009; but see Swanepoel et al. 2013), which could have overestimated population size since leopard density estimates were biased towards protected areas. However, we regard our population estimates to be good alternatives to expert opinion estimates, which were our only other option, and our estimates generally agree with such estimates (Norton 1990; Daly et al. 2005). Second, our model did not include indirect effect of harvest, for instance related to infanticide (Creel \& Rotella 2010). Although such behaviour has been suggested to influence the demographic impacts of harvest both in leopards (Packer et al. 2009; Balme et al. 2013) and in other large carnivore species (e.g. black bears, Ursus americanus: Lecount 1987, brown bears, Ursus arctos: Swenson et al. 1997, and lions, Panthera leo: Whitman et al. 2004), there are no data available on how male turnover influence such infanticide rates in leopards. Since infanticidal mortality is already included in our model through the survival estimates, we do not believe that explicit incorporation of infanticidal effects in our model would render any improvements in our interpretations. Moreover, although we recognize that our models may have underestimated the influence of male biased killing (i.e. harvest), the relative strength of retaliatory killing versus harvest suggests that the inclusion of social processes in our models likely would not have change the qualitative outcome of our simulations.

To conclude, our study suggests that control of legal and illegal killing related to human-carnivore conflict may be more effective in promoting the persistence of large carnivore populations than setting restricted trophy harvest quotas. Because we found limited effects of variation in harvest on population persistence, trophy harvest could be one potential avenue for such conflict mitigation. Our study further highlights the necessity for accurate estimates of legal and illegal retaliatory killing for any reliable assessment of sustainable harvest levels. Although our simulations suggested low extinction risk for the South African leopard population within the next 25 years, they indicated very high probabilities of population decline. Our study therefore calls for concern regarding the long-term viability of the South African leopard population. However, because of the large effects of retaliatory killing compared to harvest, we suggest that actions directed to decrease conflict-related killing of leopards may be more effective than restricting trophy harvest in securing the long-term viability of South African leopards.

\section{ACKNOWLEDGEMENTS}

Funding for the project was received from International Foundation for Science grant no. D/4984-1, 
Wild Foundation grant no. 2008-011, Wilson Foundation, University of Pretoria and the Endangered Wildlife Trust. L.H.S. was further supported by National Research Foundation of South Africa (NRF) grant no. 74819, F.D. was supported by a research fellowship from the University of Pretoria, M.S. by the DST-NRF Centre of Excellence for Invasion Biology and F.D. and M.S. were supported by the NRF.

\section{REFERENCES}

BAILEY, T.N. 2005. The African leopard: ecology and behaviour of a solitary felid. Columbia University Press, New York.

BAKER, P.J., BOITANI, L., HARRIS, S., SAUNDERS, G. \& WHITE, P.C.L. 2008. Terrestrial carnivores and human food production: impact and management. Mamm. Rev. 38: 123-166.

BALME, G.A., SLOTOW, R. \& HUNTER, L.T.B. 2009. Impact of conservation interventions on the dynamics and persistence of a persecuted leopard (Panthera pardus) population. Biol. Conserv. 142: 2681-2690.

BALME, G.A., SLOTOW, R. \& HUNTER, L.T.B. 2010. Edge effects and the impact of non-protected areas in carnivore conservation: leopards in the PhindaMkhuze Complex, South Africa. Anim. Conserv. 13: 315-323.

BALME, G.A., BATCHELOR, A., DE WORONIN BRITZ, N., SEYMOUR, G., GROVER, M., HES, L., MACDONALD, D.W. \& HUNTER, L. 2013. Reproductive success of female leopards Panthera pardus: the importance of top-down processes. Mamm. Rev. 43: 221-237.

CARO, T.M., YOUNG, C.R., CAULDWELL, A. E. \& BROWN, D.D.E. 2009. Animal breeding systems and big game hunting: models and application. Biol. Conserv. 142: 909-929.

CHASE-GREY, J.N. 2011. Leopard population dynamics, trophy hunting and conservation in the Soutpansberg Mountains, South Africa. Ph.D. thesis, Durham University, Durham. Available at Durham E-Theses Online: http://etheses.dur.ac.uk/823/ (accessed December 2013).

CREEL, S. \& ROTELLA, J.J. 2010. Meta-analysis of relationships between human offtake, total mortality and population dynamics of gray wolves (Canis lupUS). PLOS ONE 5: e12918.

CROSS, P.C. \& BEISSINGER, S.R. 2001. Using logistic regression to analyze the sensitivity of PVA models: a comparison of methods based on African wild dog models. Conserv. Biol. 15: 1335-1346.

DALERUM, F., SHULTS, B. \& KUNKEL, K. 2008. Estimating sustainable harvest in wolverine populations using logistic regression. J. Wildlife Manage. 72: 1125-1132.

DALY, B., POWER, J., CAMACHO, G., TRAYLOR HOLZER, K., BARBER, S., CATTERALL, S., FLECTHER, P., MARTINS, Q., OWEN, C., THAL, T.\& FRIEDMAN, Y. 2005. Leopard (Panthera pardus) population and habitat viability assessment. Unpublished report. Conservation Breeding Specialist
Group (SSC / IUCN) / CBSG and Endangered Wildlife Trust, Johannesburg.

DAR, N.I., MINHAS, R.A., ZAMAN, Q. \& LINKIE, M. 2009. Predicting the patterns, perceptions and causes of human-carnivore conflict in and around Machiara National Park, Pakistan. Biol. Conserv. 142: 2076-2082.

DICKMAN, A.J. 2010. Complexities of conflict: the importance of considering social factors for effectively resolving human-wildlife conflict. Anim. Conserv. 13: 458-466.

FRIEDMANN, Y. \& DALY, B. 2004. Red Data Book of the mammals of South Africa: a conservation assessment. Conservation Breeding Specialist Group (SS/IUCN) and Endangered Wildlife Trust, Johannesburg.

FUNSTON, P.J., GROOM, R.J. \& LINDSEY, P.A. 2013. Insights into the management of large carnivores for profitable wildlife-based land uses in African savannas. PLOS ONE 8: e59044.

INSKIP, C. \& ZIMMERMAN, A. 2009. Human-felid conflict: a review of patterns and priorities worldwide. Oryx 43: 18-34.

KACZENSKY, P., JERINA, K., JONOZOVIČ, M., KROFEL, M., SKRBINŠEK, T., RAUER, G., KOS, I. \& GUTLEB, B. 2011. Illegal killings may hamper brown bear recovery in the Eastern Alps. Ursus 22: 37-46.

KAUFMAN, R.L. 1996. Comparing effects in dichotomous logistic regression: a variety of standardized coefficients. Soc. Sci. Q. 77: 90-109.

LECOUNT, A. L. 1987. Causes of black bear cub mortality. Int. Conf. Bear Res. Manage. 7: 75-82.

LEWIS, D. \& JACKSON, J. 2005. Safari hunting and conservation on communal land in southern Africa. In: R. Woodroffe, S.J. Thirgood \& A. Rabinowitz (Eds), People and wildlife: conflict or coexistence? (pp. 239-252). Cambridge University Press, Cambridge.

LINDSEY, P.A., ROULET, P.A.\& ROMANACH, S.S. 2007. Economic and conservation significance of the trophy hunting industry in sub-Saharan Africa. Biol. Conserv. 134: 455-469.

LINDSEY, P.A., MARNEWICK, K., BALME, G. \& SWANEPOEL, L.H. 2011. Non detriment finding assessment for the trophy hunting of leopards in South Africa. Report for the South African National Biodiversity Institute (SANBI). Endangered Wildlife Trust, Johannesburg.

LINDSEY, P.A., BALME, G.A., BOOTH, V.R. \& MIDLANE, N. 2012. The significance of African lions for the financial viability of trophy hunting and the maintenance of wild land. PLOS ONE 7: e29332.

LINNELL, J.D.C., ANDERSEN, R., KVAM, T., ANDREN, H., LIBERG, O., ODDEN, J. \& MOA, P.F. 2001. Home range size and choice of management strategy for lynx in Scandinavia. Environ. Manage. 27: 869-879.

LOVERIDGE, A.J., PACKER, C. \& DUTTON, A. 2009. Science and the recreational hunting of lions. In: B. Dickson, J. Hutton \& W.M. Adams (Eds), Recreational hunting, conservation and rural livelihoods' (pp. 108-124). Blackwell Publishing, Oxford.

MADDEN, F. 2004. Creating coexistence between humans and wildlife: global perspectives on local 
efforts to address human-wildlife conflict. Hum. Dimens. Wildl. 9: 247-257.

MARTIN, R.B. \& DE MEULENAAR, T. 1988. Survey of the status of the leopard (Panthera pardus) in sub-Saharan Africa. CITES Secretariat, Lausanne.

McCARTHY, M.A., BURGMAN, M.A. \& FERSON, S. 1995. Sensitivity analysis for models of population viability. Biol. Conserv. 73: 93-100.

McCARTHY, M.A., BURGMAN, M.A. \& FERSON, S. 1996. Logistic sensitivity and bounds for extinction risks. Ecol. Model. 86: 297-303.

NORTON, P. M. 1990. How many leopards? A criticism of Martin and de Meulenaer's population estimates for Africa. S. Afr. J. Sci. 86: 218-219.

NOSS, R.F., QUIGLEY, H.B., HORNOCKER, M.G., MERRILL, T. \& PAQUET, P.C. 1996. Conservation biology and carnivore conservation in the Rocky Mountains. Conserv. Biol. 10: 949-963.

OGADA, M.O., WOODROFFE, R., OGUGE, N.O. \& FRANK, L.F. 2003. Limiting depredation by African carnivores: the role of livestock husbandry. Conserv. Biol. 17: 1521-1530.

PACKER, C., KOSMALA, M., COLLEY, H.S., BRINK, H., PINTEA, L., GARSHELIS, D., PURCHASE, G., STRAUSS, M., SWANSON, A., BALME, G., HUNTER, L. \& NOWELL, K. 2009. Sport hunting, predator control and conservation of large carnivores. PLOS ONE 4: e5941.

PACKER, C., BRINK, H., KISSUI, B.M., MALITI, H., KUSHNIR, H. \& CARO, T. 2011. Effects of trophy hunting on lion and leopard populations in Tanzania. Conserv. Biol. 25: 142-153.

PE'ER, G.U.Y., MATSINOS, Y.G., JOHST, K., FRANZ, K.W., TURLURE, C., RADCHUK, V., MALINOWSKA, A.H., CURTIS, J.M.R., NAUJOKAITIS-LEWIS, I., WINTLE, B.A.\& HENLE, K. 2013. A protocol for better design, application, and communication of population viability analyses. Conserv. Biol. 27: 644656.

PURVIS, A., GITTLEMAN, J.L., COWLISHAW, G. \& MACE, G. M. 2000. Predicting extinction risk in declining species. Proc. R. Soc. Lond. B. 267: 1947-1952.

REED, J.M., MILLS, L.S., DUNNING JR, J.B., MENGES, E.S., McKELVEY, K.S., FRYE, R., BEISSINGER, S.R., ANSTETT, M. \& MILLER P. 2002. Emerging issues in population viability analysis. Conserv. Biol. 16: 7-19.

STARFIELD, A.M. 1997. A pragmatic approach to modelling for wildlife management. J. Wildl. Manage. 61: 261-270.

STEIN, A.B., FULLER, T.K., DAMERY, D.T., SIEVERT, L.
\& MARKER, L.L. 2010. Farm management and economic analyses of leopard conservation in northcentral Namibia. Anim. Conserv. 13: 419-427.

SWANEPOEL, L.H, LINDSEY, P., SOMERS, M.J., VAN HOVEN, W. \& DALERUM, F. 2013. Extent and fragmentation of suitable leopard habitat in South Africa. Anim. Conserv. 16: 41-50.

SWANEPOEL, L.H., SOMERS, M.J., VAN HOVEN, W., SCHEISS-MEJIER, M., OWEN, C., SNYMAN, A., MARTINS, Q., CAMACHO, G., BOSHOFF, W. \& DALERUM, F. In press. Survival rates and causes of mortality of leopards (Panthera pardus) in southern Africa. Oryx

SWENSON, J.E. \& ANDRÉN, H. 2005. A tale of two countries: large carnivore depredation and compensation schemes in Sweden and Norway. In: R. Woodroffe, S. Thirgood \& A. Rabinowitz (Eds), People and wildlife: conflict or coexistence? (pp. 323-339). Cambridge University Press, Cambridge.

SWENSON, J.E., SANDEGREN, F., SODERBERG, A., BJARVALL, A., FRANZEN, R. \& WABAKKEN, P. 1997. Infanticide caused by hunting of male bears. Nature 386: 450-451.

THORN, M., GREEN, M., DALERUM, F., BATEMAN, P. W. \& SCOTT, D.M. 2012. What drives human-carnivore conflict in the North West Province of South Africa? Biol. Conserv. 150: 23-32.

TREVES, A. 2009. Hunting for large carnivore conservation. J. Appl. Ecol. 46: 1350-1356.

TREVES, A. \& KARANTH, K.U. 2003. Human-carnivore conflict and perspectives on carnivore management worldwide. Conserv. Biol. 17: 1491-1499.

TREVES, A. \& MARTIN, K.A. 2011. Hunters as stewards of wolves in Wisconsin and the Northern Rocky Mountains, USA. Soc. Natur. Resour. 24: 984-994.

VANDERWAL, J., SHOO, L.P., JOHNSON, C.N. \& WILLIAMS, S.E. 2009. Abundance and the environmental niche: environmental suitability estimated from niche models predicts the upper limit of local abundance. Am. Nat. 174: 282-291.

WHITMAN, K., STARFIELD, A.M., QUADLING, H.S. \& PACKER, C. 2004. Sustainable trophy hunting of African lions. Nature 428: 175-178.

WOODROFFE, R. \& GINSBERG, J.R. 1998. Edge effects and the extinction of populations inside protected areas. Science 280: 2126-2128.

WOODROFFE, R. \& FRANK, L.G. 2005 Lethal control of African lions (Panthera leo): local and regional population impacts. Anim. Conserv. 8: 91-98. 
APPENDIX 1. Parameters used for modelling the effects of leopard harvest on the probability of population decline and probability of extinction in South African leopard population. Fecundity, survival and dispersal were in the simulations regarded as Poisson and binomially distributed, respectively. Therefore, the variances of these estimates were regarded to be equal to the mean. Age and sex structure of harvest and retaliatory killing were kept as fixed throughout all simulations, to enhance the focus on variability in harvest and retaliatory killing per se.

\begin{tabular}{|c|c|}
\hline Parameter & Value \\
\hline Fecundity $^{a}$ & 1.41 \\
\hline Survival & \\
\hline adult male $e^{b}$ & 0.91 \\
\hline adult female ${ }^{b}$ & 0.85 \\
\hline subadult male ${ }^{b}$ & 0.82 \\
\hline subadult female ${ }^{b}$ & 0.91 \\
\hline juveniles $^{\mathrm{b}}$ & 0.33 \\
\hline Dispersal $^{C}$ & \\
\hline subadult males & $47 \%$ \\
\hline subadult females & $14 \%$ \\
\hline adults & $5 \%$ \\
\hline Trophy harvest $^{d}$ & \\
\hline age structure & $95 \%$ \\
\hline sex ratio & $68 \%$ \\
\hline Damage-causing animals ${ }^{e}$ & \\
\hline age structure & $72 \%$ \\
\hline sex ratio & $65 \%$ \\
\hline
\end{tabular}

aMedian from Bailey (2005), Owen (2006), Martin \& de Meulenaar (1988), Balme et al. (2009; 2010), expressed as number of offspring per female per year.

${ }^{\text {bS }}$ urvival based on protected area estimates from the meta-analysis in Swanepoel et al. (in press).

'Subadult dispersal based on 36 collared subadults taken from Bailey (2005), Balme et al. (2010), Bothma et al. (1997), Owen (2006), Stander et al. (1997), expressed as percentage animals dispersing per year.

${ }^{\mathrm{d} D a t a}$ on demographic structure of trophy harvested animals collected from Conservation offices based on hunter return forms in Limpopo Province, South Africa, $n=47$. Age structure is expressed as percentage adults and sex ratio as percentage males.

${ }^{e}$ Data on demographic structure of destroyed problem leopards in Limpopo Province $(n=21)$ and Cape Province (currently Eastern Cape Province, Western Cape Province and Northern Cape Province) $(n=37)$. Data from Limpopo Province were collected directly from conservation offices and data from the Cape Province data taken from C, Stuart and T, Stuart, unpubl. data. Age structure is expressed as percentage adults and sex ratio as percentage males. 


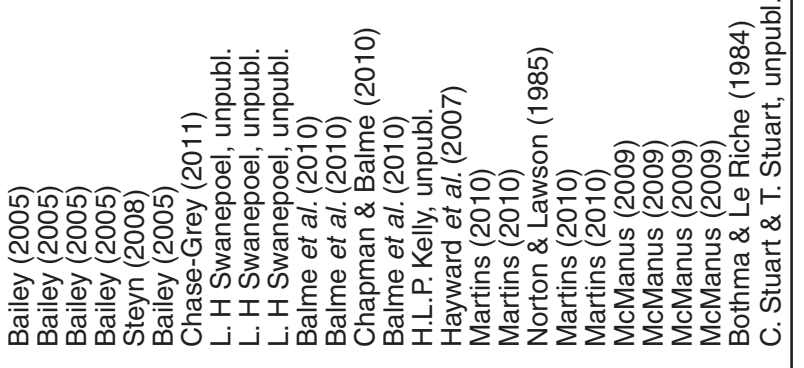

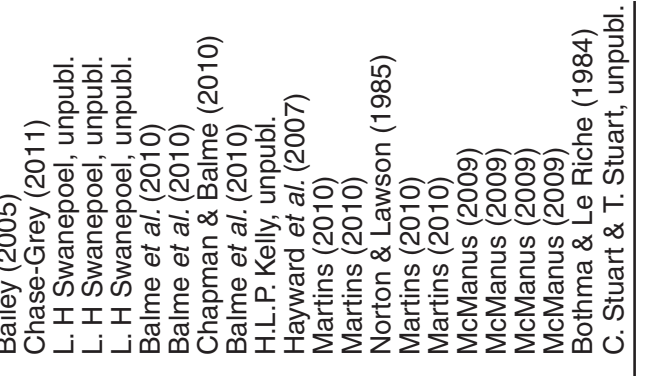

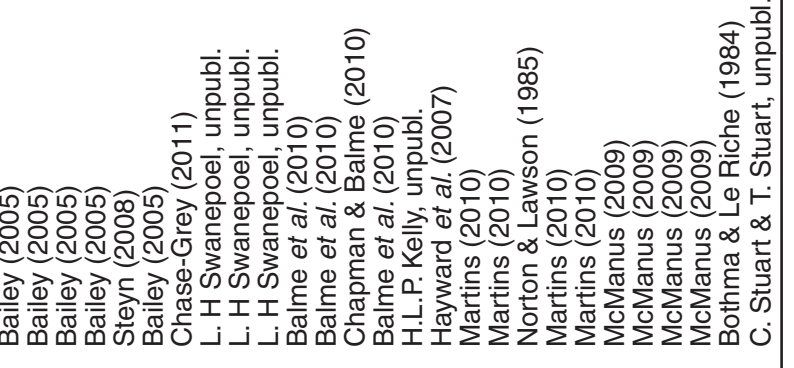<smiles>[Si]=C[Si]=C[Si]=[Se]</smiles>

ิㅗㅇㅇㅇㅇㅇㅇㅇ

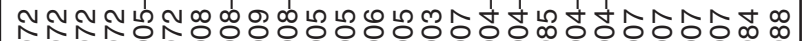

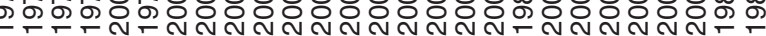

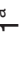

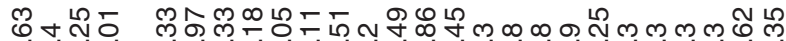

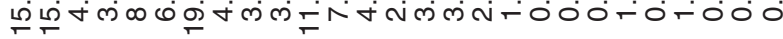

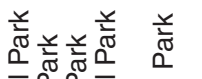

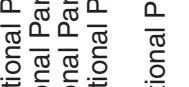

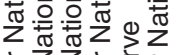

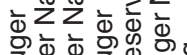

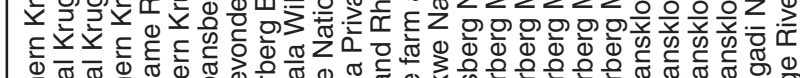

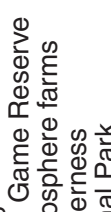

$\sum_{\substack{0 \\ 0}}$

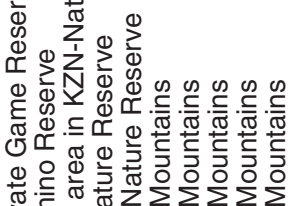

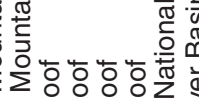

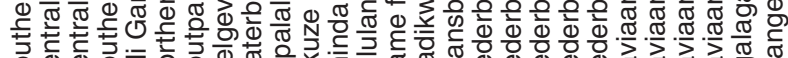

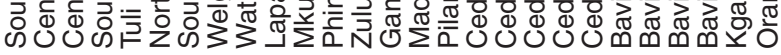

.

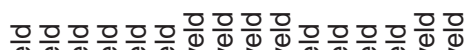

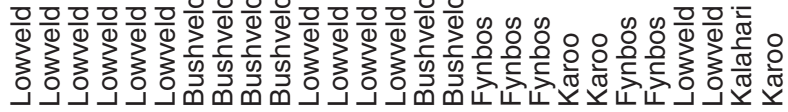

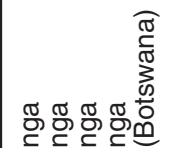

匹 匹

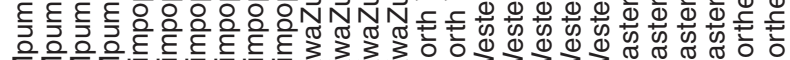


APPENDIX 3. Minimum, median and maximum leopard densities used in each provincial biome to calculate leopard population sizes in each South African province.

\begin{tabular}{|c|c|c|c|c|}
\hline \multirow[t]{2}{*}{ Province } & \multirow[t]{2}{*}{ Biome/bioregion } & \multicolumn{3}{|c|}{ Density (leopards/100km²) } \\
\hline & & Minimum & Median & Maximum \\
\hline Mpumalanga $^{a}$ & Lowveld & 3.01 & 9.80 & 15.63 \\
\hline Mpumalanga $^{b}$ & Bushveld & 3.05 & 3.76 & 19.97 \\
\hline Mpumalanga $^{c}$ & Grassland $^{d}$ & 0.25 & 0.60 & 0.90 \\
\hline $\operatorname{Limpopo}^{\mathrm{e}}$ & Lowveld & 6.33 & 7.20 & 15.60 \\
\hline Limpopo $^{\dagger}$ & Bushveld & 3.01 & 3.76 & 19.97 \\
\hline KwaZulu Natal ${ }^{g}$ & Lowveld & 2.49 & 5.86 & 11.21 \\
\hline KwaZulu Natal $^{c}$ & Grassland $^{d}$ & 0.25 & 0.60 & 0.90 \\
\hline North West ${ }^{h}$ & Bushveldi & 3.45 & 3.66 & 3.86 \\
\hline North West ${ }^{j}$ & Kalahari & 0.31 & 0.62 & 1.24 \\
\hline North West ${ }^{c}$ & Grassland $^{d}$ & 0.25 & 0.60 & 0.90 \\
\hline Gauteng $^{\text {h }}$ & Bushveldi & 3.45 & 3.66 & 3.86 \\
\hline Gauteng $^{\mathrm{C}}$ & Grassland $^{d}$ & 0.25 & 0.60 & 0.90 \\
\hline Free State $^{h}$ & Bushveldi & 3.45 & 3.66 & 3.86 \\
\hline Free State $^{c}$ & Grassland $^{d}$ & 0.25 & 0.60 & 0.90 \\
\hline Free State ${ }^{c}$ & Karoo & 0.25 & 0.60 & 0.90 \\
\hline Northern Cape ${ }^{k}$ & Fynbos' & 0.80 & 1.30 & 2.30 \\
\hline Northern Cape & Kalahari & 0.30 & 0.62 & 1.24 \\
\hline Northern Cape ${ }^{c}$ & Karoo & 0.25 & 0.60 & 0.90 \\
\hline Western Cape ${ }^{k}$ & Fynbos' & 0.80 & 1.30 & 2.30 \\
\hline Western Cape ${ }^{c}$ & Karoo & 0.25 & 0.60 & 0.90 \\
\hline Eastern Cape ${ }^{m}$ & Fynbos & 0.30 & 0.80 & 1.30 \\
\hline Eastern Cape ${ }^{m}$ & Lowveld & 0.30 & 0.80 & 1.30 \\
\hline Eastern Cape ${ }^{c}$ & Karoo & 0.25 & 0.60 & 0.90 \\
\hline Eastern Cape ${ }^{c}$ & Grassland $^{d}$ & 0.25 & 0.60 & 0.90 \\
\hline
\end{tabular}

Study numbers below taken from literature sources outlined in Appendix 2.

${ }^{a}$ Min taken from study 4, median calculated from studies 1-4, and max taken from study 1.

${ }^{\mathrm{b}} \mathrm{Min}$ taken from study 10 , median calculated from studies $7-10$, and max taken from study 7 .

'Min taken from study 21, median calculated from studies 20, 21, 27, and max taken from study 20.

${ }^{d}$ We assumed equal leopard densities in the Grassland biome as in the Karroo biome in all provinces.

${ }^{e}$ Min taken from study 6, median calculated from studies 5-6, and max taken from study 5.

${ }^{\mathrm{f}}$ Min taken from study 10, median calculated from studies 7-10, and max taken from study 7 .

${ }^{9}$ Min taken from study 14 , median calculated from studies 11-14, and max taken from study 11.

${ }^{h}$ Min taken from study 16, median calculated from studies 15-16, and max taken from study 15.

'We assumed equal leopard densities in the North West, Free State and Gauteng provinces in the bushveld biomes.

'Min calculated as half density from 26 , median taken from study 26 , and max calculated as the double density from study 26.

${ }^{k}$ Min taken from study 19, median calculated from studies 17,18,19, 22, 23, and max taken from study 17.

'We assumed equal leopard densities in Northern Cape and Western Cape provinces in the Fynbos biome.

min taken from study 23, median calculated from studies 22,23,24,25, and max taken from study 22.

Since we did not have estimated leopard densities for all biomes or provinces, we assumed equal leopard densities in the karoo and grasveld biome in all provinces, equal densities in the bushveld biome in the North West, Free State and Gauteng provinces, and equal densities for the fynbos biome in the Northern Cape and Western Cape. For the Kalahari biome, which only had one density estimate, we used half the estimated density as the minimum and double the estimated density as the maximum density. 
APPENDIX 4. Number of animals of each sex and age class killed for trophy harvest and under Damage Causing Animal (DCA) permits for each South African province during 2002-2010, as well as number of issued DCA permits in Limpopo (2002-2010) and KwaZulu-Natal (2005-2010).

\begin{tabular}{|c|c|c|c|c|c|c|c|c|}
\hline \multirow[t]{2}{*}{ Year } & \multirow[t]{2}{*}{ Age } & \multicolumn{3}{|c|}{ Harvest } & \multicolumn{3}{|c|}{ DCA } & \multirow{2}{*}{$\begin{array}{c}\text { DCA } \\
\text { permits }\end{array}$} \\
\hline & & Male & Female & Unknown & Male & Female & Unknown & \\
\hline
\end{tabular}

\begin{tabular}{|c|c|c|c|c|c|c|c|c|}
\hline & & & & & & & & \\
\hline 2002 & Adult & 1 & 0 & 0 & 0 & 0 & 0 & 22 \\
\hline & Subadult & 0 & 0 & 0 & 0 & 0 & 0 & \\
\hline & Unknown & 0 & 0 & 27 & 0 & 0 & 3 & \\
\hline 2003 & Adult & 4 & 1 & 0 & 1 & 0 & 0 & 13 \\
\hline & Subadult & 0 & 0 & 0 & 0 & 0 & 0 & \\
\hline & Unknown & 0 & 0 & 30 & 0 & 0 & 0 & \\
\hline 2004 & Adult & 1 & 1 & 0 & 0 & 0 & 0 & 22 \\
\hline & Subadult & 0 & 0 & 0 & 0 & 1 & 0 & \\
\hline & Unknown & 0 & 1 & 30 & 0 & 0 & 0 & \\
\hline 2005 & Adult & 1 & 1 & 0 & 0 & 0 & 0 & 17 \\
\hline & Subadult & 0 & 0 & 0 & 0 & 0 & 0 & \\
\hline & Unknown & 0 & 0 & 12 & 0 & 0 & 1 & \\
\hline 2006 & Adult & 4 & 2 & 0 & 0 & 0 & 0 & 21 \\
\hline & Subadult & 1 & 0 & 0 & 0 & 0 & 0 & \\
\hline & Unknown & 0 & 0 & 9 & 0 & 0 & 1 & \\
\hline 2007 & Adult & 6 & 2 & 0 & 0 & 0 & 0 & 46 \\
\hline & Subadult & 1 & 0 & 0 & 0 & 0 & 0 & \\
\hline & Unknown & 0 & 0 & 13 & 0 & 0 & 2 & \\
\hline 2008 & Adult & 2 & 0 & 0 & 1 & 0 & 0 & 66 \\
\hline & Subadult & 0 & 0 & 0 & 0 & 0 & & \\
\hline & Unknown & 0 & 0 & 47 & 0 & 0 & 65 & \\
\hline 2009 & Adult & 0 & 0 & 0 & 0 & 0 & 0 & 56 \\
\hline & Subadult & 0 & 0 & 0 & 0 & 0 & 1 & \\
\hline & Unknown & 0 & 0 & 65 & 0 & 0 & 57 & \\
\hline 2010 & Adult & 10 & 5 & 0 & 0 & 0 & 0 & 63 \\
\hline & Subadult & 0 & 1 & 0 & 0 & 0 & 0 & \\
\hline & Unknown & 1 & 0 & 34 & 0 & 0 & 0 & \\
\hline Mpun & & & & & & & & \\
\hline 2002 & Adult & 4 & 2 & 0 & 0 & 0 & 0 & \\
\hline & Subadult & 0 & 0 & 0 & 0 & 0 & 0 & \\
\hline & Unknown & 0 & 0 & 0 & 0 & 0 & 0 & \\
\hline 2003 & Adult & 3 & 3 & 0 & 0 & 0 & 0 & \\
\hline & Subadult & 0 & 0 & 0 & 0 & 0 & 0 & \\
\hline & Unknown & 0 & 0 & 0 & 0 & 0 & 0 & \\
\hline 2004 & Adult & 5 & 2 & 0 & 0 & 0 & 0 & \\
\hline & Subadult & 0 & 0 & 0 & 0 & 0 & 0 & \\
\hline & Unknown & 0 & 0 & 1 & 0 & 0 & 0 & \\
\hline 2005 & Adult & 4 & 3 & 0 & 0 & 0 & 0 & \\
\hline & Subadult & 0 & 0 & 0 & 0 & 0 & 0 & \\
\hline & Unknown & 0 & 0 & 0 & 0 & 0 & 0 & \\
\hline 2006 & Adult & 4 & 2 & 0 & 0 & 0 & 0 & \\
\hline & Subadult & 0 & 0 & 0 & 0 & 0 & 0 & \\
\hline & Unknown & 0 & 0 & 0 & 0 & 0 & 0 & \\
\hline 2007 & Adult & 6 & 0 & 0 & 0 & 0 & 0 & \\
\hline & Subadult & 0 & 0 & 0 & 0 & 0 & 0 & \\
\hline
\end{tabular}




\begin{tabular}{|c|c|c|c|c|c|c|c|c|}
\hline \multirow[t]{2}{*}{ Year } & \multirow[t]{2}{*}{ Age } & \multicolumn{3}{|c|}{ Harvest } & \multicolumn{3}{|c|}{ DCA } & \multirow{2}{*}{$\begin{array}{c}\text { DCA } \\
\text { permits }\end{array}$} \\
\hline & & Male & Female & Unknown & Male & Female & Unknown & \\
\hline & Unknown & 0 & 0 & 0 & 0 & 0 & 0 & \\
\hline \multirow[t]{3}{*}{2008} & Adult & 5 & 2 & 2 & 0 & 0 & 0 & \\
\hline & Subadult & 0 & 0 & 0 & 0 & 0 & 0 & \\
\hline & Unknown & 0 & 0 & 0 & 0 & 0 & 1 & \\
\hline \multirow[t]{3}{*}{2009} & Adult & 2 & 2 & 0 & 0 & 0 & 0 & \\
\hline & Subadult & 0 & 0 & 0 & 0 & 0 & 0 & \\
\hline & Unknown & 0 & 0 & 0 & 0 & 0 & 0 & \\
\hline \multirow[t]{3}{*}{2010} & Adult & 0 & 0 & 0 & 0 & 0 & 0 & \\
\hline & Subadult & 0 & 0 & 0 & 0 & 0 & 0 & \\
\hline & Unknown & 0 & 0 & 7 & 0 & 0 & 0 & \\
\hline
\end{tabular}

\section{North West}

2002

\begin{tabular}{llllllll}
2002 & Adult & 0 & 0 & 0 & 0 & 0 & 0 \\
& Subadult & 0 & 0 & 0 & 0 & 0 & 0 \\
& Unknown & 0 & 0 & 0 & 0 & 0 & 0 \\
\hline 2003 & Adult & 0 & 0 & 0 & 0 & 0 & 0 \\
& Subadult & 0 & 0 & 0 & 0 & 0 & 0 \\
& Unknown & 0 & 0 & 19 & 0 & 0 & 0 \\
\hline 2004 & Adult & 0 & 0 & 0 & 0 & 0 & 0 \\
& Subadult & 0 & 0 & 0 & 0 & 0 & 0 \\
& Unknown & 0 & 0 & 17 & 0 & 0 & 0 \\
\hline 2005 & Adult & 7 & 0 & 0 & 0 & 0 & 0 \\
& Subadult & 0 & 0 & 0 & 0 & 0 & 0 \\
& Unknown & 0 & 0 & 0 & 0 & 0 & 0 \\
\hline 2006 & Adult & 11 & 0 & 0 & 0 & 0 & 0 \\
& Subadult & 0 & 0 & 0 & 0 & 0 & 0 \\
& Unknown & 0 & 0 & 0 & 0 & 0 & 0 \\
\hline 2007 & Adult & 3 & 0 & 0 & 0 & 0 & 0 \\
& Subadult & 0 & 0 & 0 & 0 & 0 & 0 \\
& Unknown & 0 & 0 & 2 & 0 & 0 & 0 \\
\hline 2008 & Adult & 8 & 0 & 0 & 0 & 0 & 0 \\
& Subadult & 0 & 0 & 0 & 0 & 0 & 0 \\
& Unknown & 0 & 0 & 0 & 0 & 0 & 0 \\
\hline 2009 & Adult & 8 & 0 & 0 & 0 & 0 & 0 \\
& Subadult & 0 & 0 & 0 & 0 & 0 & 0 \\
& Unknown & 0 & 0 & 2 & 0 & 0 & 0 \\
\hline 2010 & Adult & 4 & 0 & 0 & 0 & 0 & 0 \\
& Subadult & 0 & 0 & 0 & 0 & 0 & 0 \\
& Unknown & 0 & 0 & 3 & 0 & 0 & 0 \\
\hline & & & & & & &
\end{tabular}

\section{Gauteng}

2002

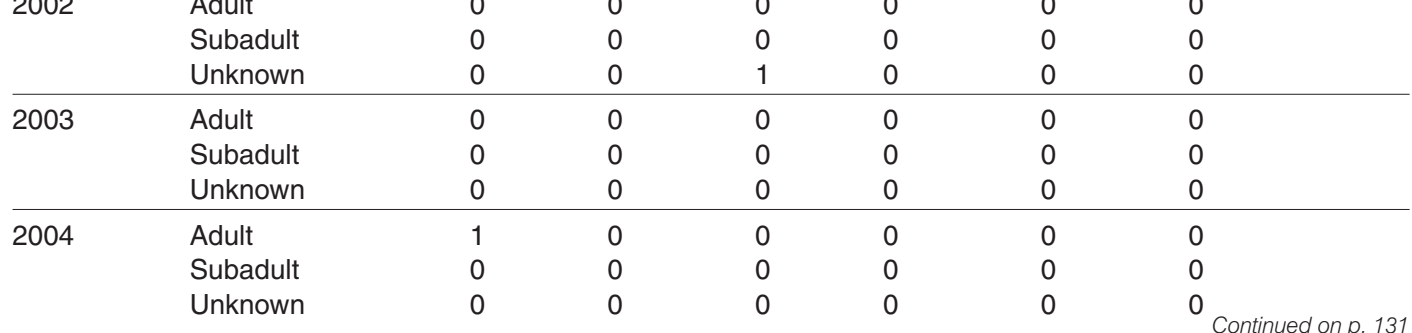




\begin{tabular}{|c|c|c|c|c|c|c|c|c|}
\hline \multirow[t]{2}{*}{ Year } & \multirow[t]{2}{*}{ Age } & \multicolumn{3}{|c|}{ Harvest } & \multicolumn{3}{|c|}{ DCA } & \multirow{2}{*}{$\begin{array}{c}\text { DCA } \\
\text { permits }\end{array}$} \\
\hline & & Male & Female & Unknown & Male & Female & Unknown & \\
\hline \multirow[t]{3}{*}{2005} & Adult & 0 & 0 & 0 & 0 & 0 & 0 & \\
\hline & Subadult & 0 & 0 & 0 & 0 & 0 & 0 & \\
\hline & Unknown & 0 & 0 & 2 & 0 & 0 & 0 & \\
\hline \multirow[t]{3}{*}{2006} & Adult & 0 & 0 & 0 & 0 & 0 & 0 & \\
\hline & Subadult & 0 & 0 & 0 & 0 & 0 & 0 & \\
\hline & Unknown & 0 & 0 & 0 & 0 & 0 & 0 & \\
\hline \multirow[t]{3}{*}{2007} & Adult & 0 & 0 & 0 & 0 & 0 & 0 & \\
\hline & Subadult & 0 & 0 & 0 & 0 & 0 & 0 & \\
\hline & Unknown & 0 & 0 & 0 & 0 & 0 & 0 & \\
\hline \multirow[t]{3}{*}{2008} & Adult & 0 & 0 & 0 & 0 & 0 & 0 & \\
\hline & Subadult & 0 & 0 & 0 & 0 & 0 & 0 & \\
\hline & Unknown & 0 & 0 & 0 & 0 & 0 & 0 & \\
\hline \multirow[t]{3}{*}{2009} & Adult & 0 & 0 & 0 & 0 & 0 & 0 & \\
\hline & Subadult & 0 & 0 & 0 & 0 & 0 & 0 & \\
\hline & Unknown & 0 & 0 & 0 & 0 & 0 & 0 & \\
\hline \multirow[t]{3}{*}{2010} & Adult & 0 & 0 & 0 & 0 & 0 & 0 & \\
\hline & Subadult & 0 & 0 & 0 & 0 & 0 & 0 & \\
\hline & Unknown & 0 & 0 & 0 & 0 & 0 & 0 & \\
\hline
\end{tabular}

\section{Northern Cape}

\begin{tabular}{|c|c|c|c|c|c|c|c|}
\hline \multirow[t]{3}{*}{2002} & Adult & 0 & 0 & 0 & 0 & 0 & 0 \\
\hline & Subadult & 0 & 0 & 0 & 0 & 0 & 0 \\
\hline & Unknown & 0 & 0 & 0 & 0 & 0 & 0 \\
\hline \multirow[t]{3}{*}{2003} & Adult & 0 & 0 & 0 & 0 & 0 & 0 \\
\hline & Subadult & 0 & 0 & 0 & 0 & 0 & 0 \\
\hline & Unknown & 0 & 0 & 0 & 0 & 0 & 0 \\
\hline \multirow[t]{3}{*}{2004} & Adult & 0 & 0 & 0 & 0 & 0 & 0 \\
\hline & Subadult & 0 & 0 & 0 & 0 & 0 & 0 \\
\hline & Unknown & 0 & 0 & 0 & 0 & 0 & 0 \\
\hline \multirow[t]{3}{*}{2005} & Adult & 0 & 0 & 0 & 0 & 0 & 0 \\
\hline & Subadult & 0 & 0 & 0 & 0 & 0 & 0 \\
\hline & Unknown & 0 & 0 & 0 & 0 & 0 & 0 \\
\hline \multirow[t]{3}{*}{2006} & Adult & 0 & 0 & 0 & 0 & 0 & 0 \\
\hline & Subadult & 0 & 0 & 0 & 0 & 0 & 0 \\
\hline & Unknown & 0 & 0 & 0 & 0 & 0 & 1 \\
\hline \multirow[t]{3}{*}{2007} & Adult & 0 & 0 & 0 & 0 & 0 & 0 \\
\hline & Subadult & 0 & 0 & 0 & 0 & 0 & 0 \\
\hline & Unknown & 0 & 0 & 0 & 0 & 0 & 1 \\
\hline \multirow[t]{3}{*}{2008} & Adult & 0 & 0 & 0 & 0 & 0 & 0 \\
\hline & Subadult & 0 & 0 & 0 & 0 & 0 & 0 \\
\hline & Unknown & 0 & 0 & 0 & 0 & 0 & 3 \\
\hline \multirow[t]{3}{*}{2009} & Adult & 0 & 0 & 0 & 0 & 0 & 0 \\
\hline & Subadult & 0 & 0 & 0 & 0 & 0 & 0 \\
\hline & Unknown & 0 & 0 & 0 & 0 & 0 & 1 \\
\hline \multirow[t]{3}{*}{2010} & Adult & 0 & 0 & 0 & 0 & 0 & 0 \\
\hline & Subadult & 0 & 0 & 0 & 0 & 0 & 0 \\
\hline & Unknown & 0 & 0 & 0 & 0 & 0 & 0 \\
\hline \multicolumn{8}{|c|}{ Free State } \\
\hline \multirow[t]{2}{*}{2002} & Adult & 0 & 0 & 0 & 0 & 0 & 0 \\
\hline & Subadult & 0 & 0 & 0 & 0 & 0 & 0 \\
\hline
\end{tabular}




\begin{tabular}{|c|c|c|c|c|c|c|c|c|}
\hline \multirow[t]{2}{*}{ Year } & \multirow[t]{2}{*}{ Age } & \multicolumn{3}{|c|}{ Harvest } & \multicolumn{3}{|c|}{ DCA } & \multirow{2}{*}{$\begin{array}{c}\text { DCA } \\
\text { permits }\end{array}$} \\
\hline & & Male & Female & Unknown & Male & Female & Unknown & \\
\hline & Unknown & 0 & 0 & 0 & 0 & 0 & 0 & \\
\hline \multirow[t]{3}{*}{2003} & Adult & 0 & 0 & 0 & 0 & 0 & 0 & \\
\hline & Subadult & 0 & 0 & 0 & 0 & 0 & 0 & \\
\hline & Unknown & 0 & 0 & 0 & 0 & 0 & 0 & \\
\hline \multirow[t]{3}{*}{2004} & Adult & 0 & 0 & 0 & 0 & 0 & 0 & \\
\hline & Subadult & 0 & 0 & 0 & 0 & 0 & 0 & \\
\hline & Unknown & 0 & 0 & 0 & 0 & 0 & 0 & \\
\hline \multirow[t]{3}{*}{2005} & Adult & 0 & 0 & 0 & 0 & 0 & 0 & \\
\hline & Subadult & 0 & 0 & 0 & 0 & 0 & 0 & \\
\hline & Unknown & 0 & 0 & 0 & 0 & 0 & 0 & \\
\hline \multirow[t]{3}{*}{2006} & Adult & 0 & 0 & 0 & 0 & 0 & 0 & \\
\hline & Subadult & 0 & 0 & 0 & 0 & 0 & 0 & \\
\hline & Unknown & 0 & 0 & 0 & 0 & 0 & 0 & \\
\hline \multirow[t]{3}{*}{2007} & Adult & 0 & 0 & 0 & 0 & 0 & 0 & \\
\hline & Subadult & 0 & 0 & 0 & 0 & 0 & 0 & \\
\hline & Unknown & 0 & 0 & 0 & 0 & 0 & 0 & \\
\hline \multirow[t]{3}{*}{2008} & Adult & 0 & 0 & 0 & 0 & 0 & 0 & \\
\hline & Subadult & 0 & 0 & 0 & 0 & 0 & 0 & \\
\hline & Unknown & 0 & 0 & 0 & 0 & 0 & 0 & \\
\hline \multirow[t]{3}{*}{2009} & Adult & 0 & 0 & 0 & 0 & 0 & 0 & \\
\hline & Subadult & 0 & 0 & 0 & 0 & 0 & 0 & \\
\hline & Unknown & 0 & 0 & 0 & 0 & 0 & 0 & \\
\hline \multirow[t]{3}{*}{2010} & Adult & 0 & 0 & 0 & 0 & 0 & 0 & \\
\hline & Subadult & 0 & 0 & 0 & 0 & 0 & 0 & \\
\hline & Unknown & 0 & 0 & 0 & 0 & 0 & 0 & \\
\hline
\end{tabular}

KwaZulu-Natal

\begin{tabular}{|c|c|c|c|c|c|c|c|c|}
\hline \multirow[t]{3}{*}{2002} & Adult & 1 & 1 & 0 & 0 & 0 & 0 & \\
\hline & Subadult & 0 & 0 & 0 & 0 & 0 & 0 & \\
\hline & Unknown & 0 & 0 & 0 & 0 & 0 & 0 & \\
\hline \multirow[t]{3}{*}{2003} & Adult & 1 & 0 & 0 & 0 & 0 & 0 & \\
\hline & Subadult & 0 & 0 & 0 & 0 & 0 & 0 & \\
\hline & Unknown & 0 & 0 & 0 & 0 & 0 & 0 & \\
\hline \multirow[t]{3}{*}{2004} & Adult & 1 & 1 & 0 & 0 & 0 & 0 & \\
\hline & Subadult & 0 & 0 & 0 & 0 & 0 & 0 & \\
\hline & Unknown & 0 & 0 & 0 & 0 & 0 & 0 & \\
\hline \multirow[t]{3}{*}{2005} & Adult & 1 & 1 & 0 & 0 & 0 & 0 & 7 \\
\hline & Subadult & 0 & 0 & 0 & 0 & 0 & 0 & \\
\hline & Unknown & 0 & 0 & 0 & 0 & 0 & 0 & \\
\hline \multirow[t]{3}{*}{2006} & Adult & 1 & 0 & 0 & 2 & 0 & 0 & 2 \\
\hline & Subadult & 0 & 0 & 0 & 0 & 0 & 0 & \\
\hline & Unknown & 0 & 0 & 0 & 0 & 0 & 2 & \\
\hline \multirow[t]{3}{*}{2007} & Adult & 0 & 1 & 0 & 0 & 0 & 0 & 5 \\
\hline & Subadult & 0 & 0 & 0 & 0 & 0 & 0 & \\
\hline & Unknown & 0 & 0 & 0 & 0 & 0 & 0 & \\
\hline \multirow[t]{3}{*}{2008} & Adult & 1 & 1 & 0 & 1 & 0 & 0 & 4 \\
\hline & Subadult & 0 & 0 & 0 & 0 & 0 & 0 & \\
\hline & Unknown & 0 & 0 & 0 & 0 & 0 & 0 & \\
\hline 2009 & Adult & 5 & 0 & 0 & 1 & 0 & 0 & 8 \\
\hline
\end{tabular}




\begin{tabular}{|c|c|c|c|c|c|c|c|c|}
\hline \multirow[t]{2}{*}{ Year } & \multirow[t]{2}{*}{ Age } & \multicolumn{3}{|c|}{ Harvest } & \multicolumn{3}{|c|}{ DCA } & \multirow{2}{*}{$\begin{array}{c}\text { DCA } \\
\text { permits }\end{array}$} \\
\hline & & Male & Female & Unknown & Male & Female & Unknown & \\
\hline & Subadult & 0 & 0 & 0 & 0 & 0 & 0 & \\
\hline & Unknown & 0 & 0 & 0 & 0 & 0 & 0 & \\
\hline \multirow[t]{3}{*}{2010} & Adult & 5 & 0 & 0 & 1 & 0 & 0 & 8 \\
\hline & Subadult & 0 & 0 & 0 & 0 & 0 & 0 & \\
\hline & Unknown & 0 & 0 & 0 & 0 & 0 & 0 & \\
\hline
\end{tabular}

\section{Western Cape}

\begin{tabular}{|c|c|c|c|c|c|c|c|}
\hline 1977 & Adult & 0 & 0 & 0 & 0 & 0 & 0 \\
\hline & Subadult & 0 & 0 & 0 & 0 & 0 & 0 \\
\hline & Unknown & 0 & 0 & 0 & 2 & 4 & 0 \\
\hline 1978 & Adult & 0 & 0 & 0 & 0 & 0 & 0 \\
\hline & Subadult & 0 & 0 & 0 & 0 & 0 & 0 \\
\hline & Unknown & 0 & 0 & 0 & 9 & 4 & 0 \\
\hline 1979 & Adult & 0 & 0 & 0 & 0 & 0 & 0 \\
\hline & Subadult & 0 & 0 & 0 & 0 & 0 & 0 \\
\hline & Unknown & 0 & 0 & 0 & 9 & 1 & 0 \\
\hline 1980 & Adult & 0 & 0 & 0 & 0 & 0 & 0 \\
\hline & Subadult & 0 & 0 & 0 & 0 & 0 & 0 \\
\hline & Unknown & 0 & 0 & 0 & 5 & 10 & 0 \\
\hline 2002 & Adult & 0 & 0 & 0 & 0 & 0 & 0 \\
\hline & Subadult & 0 & 0 & 0 & 0 & 0 & 0 \\
\hline & Unknown & 0 & 0 & 0 & 0 & 0 & 0 \\
\hline 2003 & Adult & 0 & 0 & 0 & 0 & 0 & 0 \\
\hline & Subadult & 0 & 0 & 0 & 0 & 0 & 0 \\
\hline & Unknown & 0 & 0 & 0 & 0 & 0 & 0 \\
\hline 2004 & Adult & 0 & 0 & 0 & 0 & 0 & 0 \\
\hline & Subadult & 0 & 0 & 0 & 0 & 0 & 0 \\
\hline & Unknown & 0 & 0 & 0 & 0 & 0 & 0 \\
\hline 2005 & Adult & 0 & 0 & 0 & 0 & 0 & 0 \\
\hline & Subadult & 0 & 0 & 0 & 0 & 0 & 0 \\
\hline & Unknown & 0 & 0 & 0 & 0 & 0 & 0 \\
\hline 2006 & Adult & 0 & 0 & 0 & 0 & 0 & 0 \\
\hline & Subadult & 0 & 0 & 0 & 0 & 0 & 0 \\
\hline & Unknown & 0 & 0 & 0 & 0 & 0 & 0 \\
\hline 2007 & Adult & 0 & 0 & 0 & 0 & 0 & 0 \\
\hline & Subadult & 0 & 0 & 0 & 0 & 0 & 0 \\
\hline & Unknown & 0 & 0 & 0 & 0 & 0 & 0 \\
\hline 2008 & Adult & 0 & 0 & 0 & 0 & 0 & 0 \\
\hline & Subadult & 0 & 0 & 0 & 0 & 0 & 0 \\
\hline & Unknown & 0 & 0 & 0 & 0 & 0 & 0 \\
\hline 2009 & Adult & 0 & 0 & 0 & 0 & 0 & 0 \\
\hline & Subadult & 0 & 0 & 0 & 0 & 0 & 0 \\
\hline & Unknown & 0 & 0 & 0 & 0 & 0 & 0 \\
\hline 2010 & Adult & 0 & 0 & 0 & 0 & 0 & 0 \\
\hline & Subadult & 0 & 0 & 0 & 0 & 0 & 0 \\
\hline & Unknown & 0 & 0 & 0 & 0 & 0 & 0 \\
\hline
\end{tabular}

\section{Eastern Cape}

$2002 \quad$ Adult

Subadult

Unknown

$\begin{array}{ll}0 & 0 \\ 0 & 0 \\ 0 & 0\end{array}$

$\begin{array}{ll}0 & 0 \\ 0 & 0 \\ 0 & 0\end{array}$

$\begin{array}{ll}0 & 0 \\ 0 & 0 \\ 0 & 0\end{array}$




\begin{tabular}{|c|c|c|c|c|c|c|c|c|}
\hline \multirow[t]{2}{*}{ Year } & \multirow[t]{2}{*}{ Age } & \multicolumn{3}{|c|}{ Harvest } & \multicolumn{3}{|c|}{ DCA } & \multirow{2}{*}{$\begin{array}{l}\mathrm{DCA} \\
\text { permits }\end{array}$} \\
\hline & & Male & Female & Unknown & Male & Female & Unknown & \\
\hline \multirow[t]{3}{*}{2003} & Adult & 0 & 0 & 0 & 0 & 0 & 0 & \\
\hline & Subadult & 0 & 0 & 0 & 0 & 0 & 0 & \\
\hline & Unknown & 0 & 0 & 0 & 0 & 0 & 0 & \\
\hline \multirow[t]{3}{*}{2004} & Adult & 0 & 0 & 0 & 0 & 0 & 0 & \\
\hline & Subadult & 0 & 0 & 0 & 0 & 0 & 0 & \\
\hline & Unknown & 0 & 0 & 0 & 0 & 0 & 0 & \\
\hline \multirow[t]{3}{*}{2005} & Adult & 0 & 0 & 0 & 0 & 0 & 0 & \\
\hline & Subadult & 0 & 0 & 0 & 0 & 0 & 0 & \\
\hline & Unknown & 0 & 0 & 0 & 0 & 0 & 0 & \\
\hline \multirow{3}{*}{2006} & Adult & 0 & 0 & 0 & 0 & 0 & 0 & \\
\hline & Subadult & 0 & 0 & 0 & 0 & 0 & 0 & \\
\hline & Unknown & 0 & 0 & 0 & 0 & 0 & 0 & \\
\hline \multirow[t]{3}{*}{2007} & Adult & 0 & 0 & 0 & 0 & 0 & 0 & \\
\hline & Subadult & 0 & 0 & 0 & 0 & 0 & 0 & \\
\hline & Unknown & 0 & 0 & 0 & 0 & 0 & 0 & \\
\hline \multirow[t]{3}{*}{2008} & Adult & 0 & 0 & 0 & 0 & 0 & 0 & \\
\hline & Subadult & 0 & 0 & 0 & 0 & 0 & 0 & \\
\hline & Unknown & 0 & 0 & 0 & 0 & 0 & 0 & \\
\hline \multirow[t]{3}{*}{2009} & Adult & 0 & 0 & 0 & 0 & 0 & 0 & \\
\hline & Subadult & 0 & 0 & 0 & 0 & 0 & 0 & \\
\hline & Unknown & 0 & 0 & 0 & 0 & 0 & 0 & \\
\hline \multirow[t]{3}{*}{2010} & Adult & 0 & 0 & 0 & 0 & 0 & 0 & \\
\hline & Subadult & 0 & 0 & 0 & 0 & 0 & 0 & \\
\hline & Unknown & 0 & 0 & 0 & 0 & 0 & 0 & \\
\hline
\end{tabular}

